Jurnal Quantum Teknika

Vol. 1, No. 1, Hal 33-38, Oktober 2019

\title{
Proposed Improvement To Minimize Motion Waste In Production Of Head Casing Part At Pt. Multi Instrumentasi With Lean Manufacturing Approach
}

\author{
Williardy Adhum Pratama*, Agus Alex Yanuar, Meldi Rendra \\ School of Industrial Engineering, Telkom University, Jalan Telekomunikasi no. 1, Bandung, 40257, \\ Indonesia \\ Correspondence author : williardyadhumpratama@gmail.com
}

Histori artikel: diserahkan 15 Mei 2019, direviu 15 Juli 2019, direvisi 14 Agustus 2019

\begin{abstract}
PT. Multi Instrumentasi is a manufacturing company that produces water meters. In producing water meters, one of the parts is the head casing. Head casing part consists of two types namely LF-1 and LF-2. Constraints experienced by companies are the inaccessibility of head casing production targets that can hinder the sale of water meters to consumers. For this reason, a proposal to improve the lean manufacturing approach is proposed to minimize the waste that occurs. The stage of the lean manufacturing approach is to identify the production process that occurs using the Process Activity Mapping and Value Stream Mapping. Furthermore, identifying waste that occurs using fishbone diagrams. After identifying waste, waste motion is found in the process of making the head casing part with manual lathes. Subsequently, proposed improvements were made using the Single Minutes Exchange of Die (SMED) method. After the proposed improvement, the company's profitability can be calculated by comparing the existing production costs after the proposed improvements.

Keywords: Lean manufacturing, SMED, head casing
\end{abstract}

DOI: $10.18196 /$ jqt.010106

Web: http://journal.umy.ac.id/index.php/qt

\section{INTRODUCTION}

Lean Manufacturing is a systematic approach to identifying and eliminating waste, also known as non-value added activities through continuous improvement techniques (Franchetti, 2015). The main goal of lean is to reduce costs and increase productivity by eliminating waste. Waste is the types of waste that occur in the manufacturing process or services, namely transportation, inventory, movement, waiting, excessive processing, excessive production, damaged goods (Ledbetter, 2018). Waste that occurs on the production floor is certainly very detrimental for companies, especially manufacturing companies. Due to the presence of waste on the production floor causes the production process time to be longer and result in product delivery not on time. PT. Multi Instrumentation is a manufacturing industry company included in the basic metal and electronics industry group. PT. Multi This instrumentation produces measuring equipment namely Water Meter. The company was established on August 22, 1991 and is located on Jalan Tengah Gedebage, Ujung Berung, Bandung. Products manufactured by PT. Multi This instrumentation has a trademark namely "Linflow". Next is main part of water meter compiler at PT. Multi Instrumentation.

\section{IDENTIFICATION OF PROBLEM}

PT. Multi Instrumentation produces water meters. One of the water meter parts is the head casing. The problem experienced by companies is the lack of achievement of the company's production targets. To meet production targets, companies buy products from external or commonly called 
subcontracts. But when buying from a subcontract, you can't buy only part head casings but you have to have a package with a body casing that makes the purchase price soar. The following is a table of production targets compared to the realization of production:

TABLE 1.Target and realization of production

\begin{tabular}{cccr}
\hline Month & $\begin{array}{c}\text { Production } \\
\text { Target }\end{array}$ & $\begin{array}{c}\text { Intern } \\
\text { Production }\end{array}$ & Subcontract \\
\hline $\begin{array}{c}\text { First } \\
\text { Stock }\end{array}$ & - & - & 8190 \\
\hline Januay & 1080 & - & 7024 \\
\hline February & 12000 & - & 14975 \\
\hline March & 12000 & - & 7097 \\
\hline April & 12000 & - & 15873 \\
\hline May & 12000 & - & 26110 \\
\hline June & 12000 & - & 3870 \\
\hline July & 12000 & 1460 & 9795 \\
\hline August & 12000 & 3303 & 12285 \\
\hline September & 12000 & 5020 & 13941 \\
\hline October & 12000 & 3977 & 7460 \\
\hline November & 12000 & 4286 & 2500 \\
\hline December & 12000 & 4189 & 7993 \\
\hline Total: & 142800 & 22235 & 137113 \\
\hline
\end{tabular}

\section{LITERATUR REFERENCES}

\section{Lean Manufacturing}

Lean manufacturing is a systematic approach to identifying and eliminating waste, also known as non-value-added activities through correct continuous improvement techniques. The three factors evaluated for jobs that are considered as added value are:

a. Capacity: Machines, resources, tools, and employees used in the process must have the capacity needed to produce end-value added products.

b. Information / Hints: Employees must know their final product and process to reach the final product with minimum waste or non-value-added activities.

c. Material: Material provided to workers must be free from defects and can be processed and sold in commodity markets. A worker must know which raw material is acceptable or unacceptable. (Franchetti, 2015).

\section{Process Activity Mapping}

Process Activity Mapping is a diagram that shows the sequences of operations, checks, transportation, waiting, and storage that occur during an ongoing process or procedure. It contains information needed for analysis such as the time needed in a process and the distance of displacement that occurs (Iftikar et.al, 2016)

\section{Fishbone Diagram}

A cause and effect diagram also known as a fish bone diagram or Ishikawa diagram. All causes are categorized into different categories such as humans, machines, materials, methods, measurement systems, etc (Antony, 2016)

\section{The SMED}

The SMED method is used to speed up the changeover setup time, the result of the improvement achieved is to reduce the time to set up changeover. The following is the SMED procedure:

1. Work in detail

In the first step, FLM will be displayed and it will occur to determine the dependencies and general categories there. If nothing is transported, it's not too useful to handle the transportation category. In the following cycle, the setup will be analyzed and explained step by step. Analysis of work steps becomes increasingly detailed.

2. Describe each single action

The times of each category are then summed up and expressed about the total time. Depending on the requirements, it may be necessary to describe the work step until such a detailed level for conclusions is only a list of the remaining verbs that describe every single action that the process step is made. At some point, further details may not produce additional benefits, but too low a breakdown is a problem when working on a solution.

3. Avoid Aggregation

The highest level of aggregation will be achieved if it says: "This process is regulated and it lasts for $\mathrm{x}$ hours." This is 


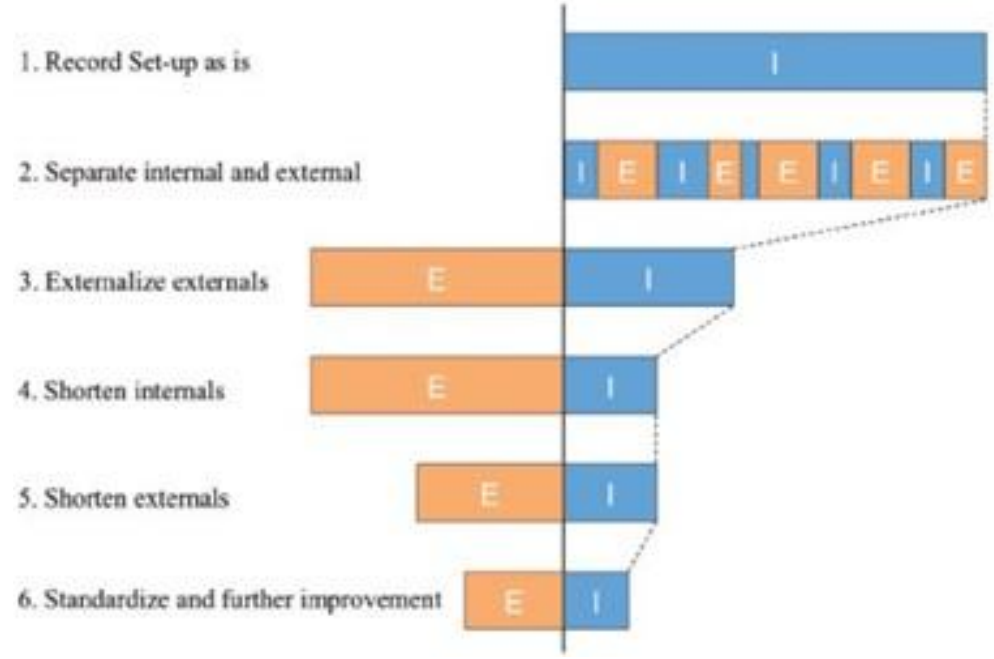

FIGURE 1. Order of SMED work

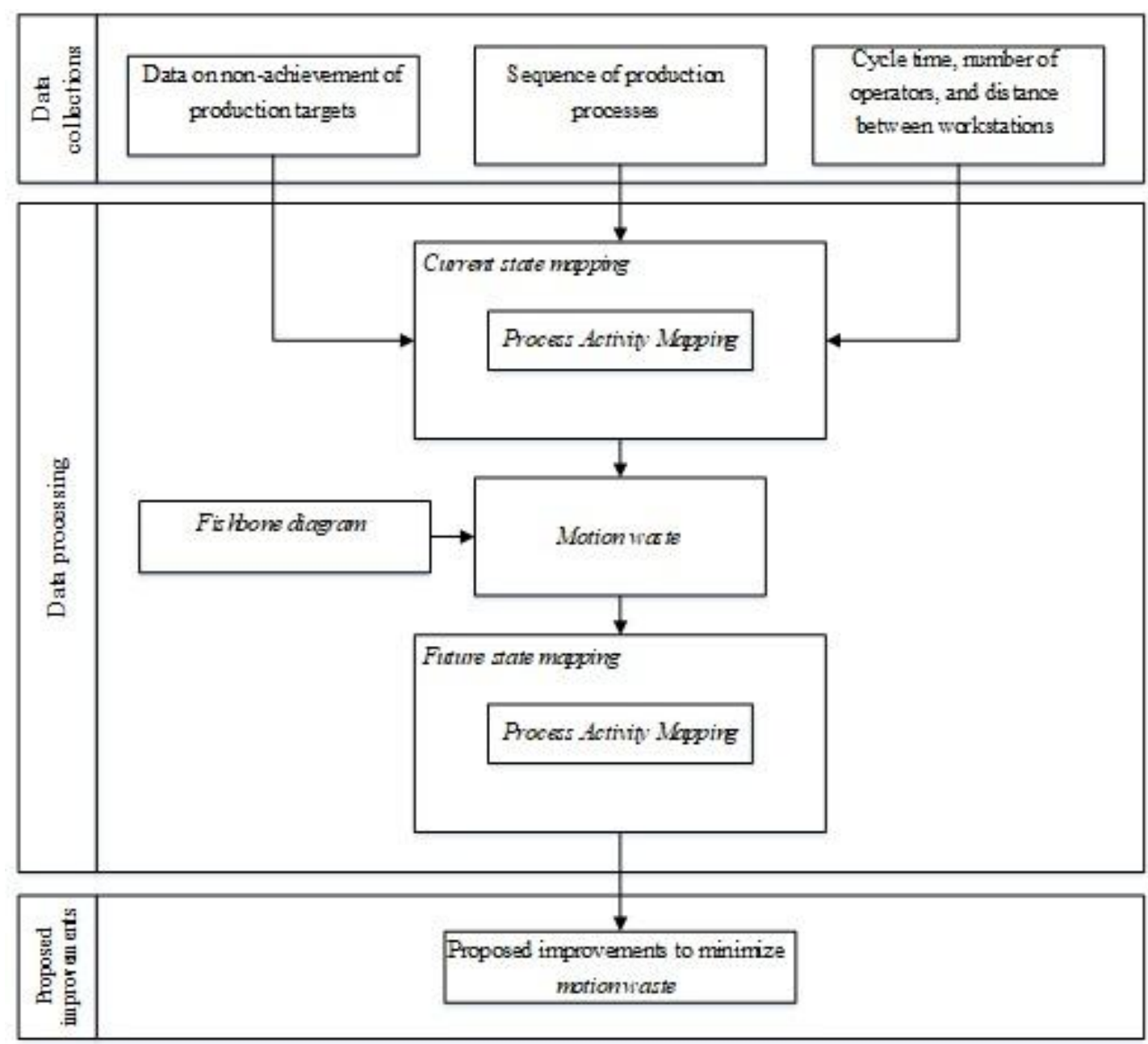

FIGURE 2. Research methodology

true, but not more than the beginning of the point, where the opportunity was seen reading this book or concentrating on the topic in detail. The reason for this effect to appear is the one mentioned earlier. Loss of supervision because it does not clearly fend off several fields and categories describing the system of sub- 
aspects in which the entire process can be

described (Herr, 2013).

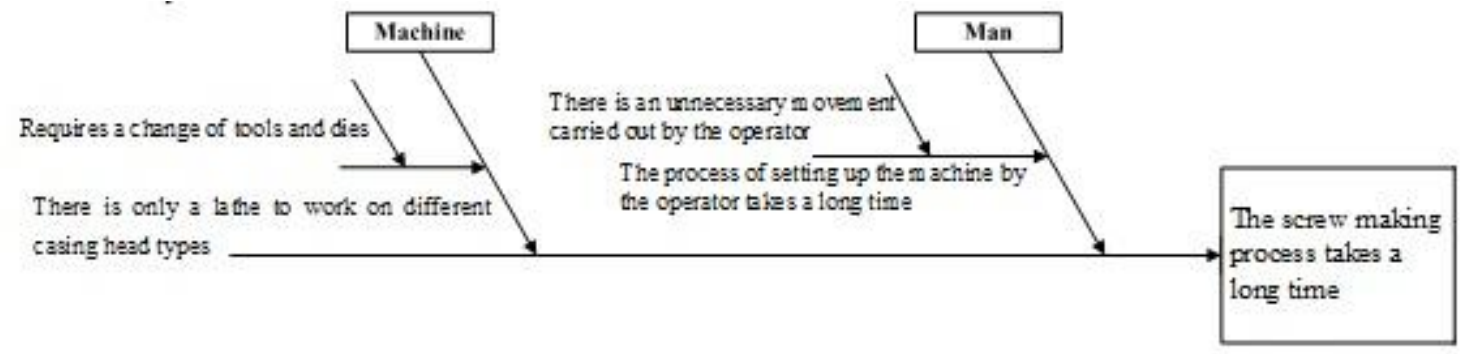

FIGURE 3. Fish bone diagram

\section{RESEARCH METHODOLOGY}

To produce output by the research objectives, a conceptual model is needed which serves to describe the concept of problem solving in a structured manner. The conceptual model that describes the stages through which can be seen in Figure 2.

Data collection is needed to identify the waste that occurs and provide proposed improvements. By using Process Activity Mapping (PAM), activities that include value added, non-value added, and non value added are obtained. The following is a PAM recapitulation.

TABLE 2. Process activity mapping summary

\begin{tabular}{ccc}
\hline Waste type & time (second) & time (minute) \\
\hline Waiting & 3618,67 & 60,31 \\
\hline Transportasi & 2692,52 & 44,88 \\
\hline Motion & 682,01 & 11,37 \\
\hline
\end{tabular}

Based on the summary of the process activity mapping above, there are three wastes in the process of making water meters, namely waiting, transportation, and motion waste. However, this study is limited to the discussion of waste motion that occurs in the process of making part head casings.

\section{PROCESSING}

\section{Proposed Improvements with SMED}

Identify activities related to the cycle time that occurred.
TABLE 3. Existing activity and cycle time for head casing part schrew making

\begin{tabular}{|c|c|c|c|c|}
\hline No. & Initial Activity & $\begin{array}{c}\text { Time } \\
\text { (second) }\end{array}$ & $\begin{array}{l}\text { Internal } \\
\text { set up }\end{array}$ & $\begin{array}{l}\text { Eksternal } \\
\text { set up }\end{array}$ \\
\hline 1 & $\begin{array}{l}\text { Place the LF-2 } \\
\text { type "head casing" } \\
\text { on the work table }\end{array}$ & 59,80 & & V \\
\hline 2 & $\begin{array}{l}\text { Go to the storage } \\
\text { cabinet to take } \\
\text { tools }\end{array}$ & 44,80 & & V \\
\hline 3 & $\begin{array}{l}\text { Return to the } \\
\text { manual lathe to set } \\
\text { up the machine }\end{array}$ & 42,63 & & V \\
\hline 4 & $\begin{array}{l}\text { Put tools on the } \\
\text { work desk }\end{array}$ & 4,89 & & V \\
\hline 5 & $\begin{array}{l}\text { Take tools and } \\
\text { demolition dies }\end{array}$ & 278,24 & V & \\
\hline 6 & $\begin{array}{l}\text { Place the tools and } \\
\text { dies that are } \\
\text { dismantled at the } \\
\text { work desk }\end{array}$ & 35,87 & & V \\
\hline 7 & $\begin{array}{l}\text { Towards a storage } \\
\text { cabinet picking up } \\
\text { new dies }\end{array}$ & 41,45 & & V \\
\hline 8 & $\begin{array}{l}\text { Look for new dies } \\
\text { in the storage } \\
\text { cabinet }\end{array}$ & 118,55 & & V \\
\hline 9 & $\begin{array}{l}\text { Return to the } \\
\text { manual lathe to } \\
\text { install new dies }\end{array}$ & 74,90 & & V \\
\hline 10 & $\begin{array}{l}\text { Take tools and } \\
\text { install new dies }\end{array}$ & 357,80 & V & \\
\hline 11 & $\begin{array}{l}\text { Returns old dies to } \\
\text { the storage cabinet }\end{array}$ & 36,09 & & V \\
\hline 12 & $\begin{array}{l}\text { Place old dies that } \\
\text { have been } \\
\text { dismantled in the } \\
\text { storage cabinet }\end{array}$ & 44,34 & & V \\
\hline 13 & $\begin{array}{l}\text { Towards a manual } \\
\text { lathe for engine } \\
\text { testing }\end{array}$ & 40,66 & & V \\
\hline 14 & $\begin{array}{l}\text { Install the casing } \\
\text { head to test it on } \\
\text { the manual lathe } \\
\text { stand }\end{array}$ & 15,39 & V & \\
\hline 15 & $\begin{array}{l}\text { Position settings } \\
\text { for tools and dies }\end{array}$ & 118,82 & V & \\
\hline 16 & $\begin{array}{l}\text { Engine testing } \\
\text { process }\end{array}$ & 19,28 & V & \\
\hline
\end{tabular}


TABLE 4. Existing activity and cycle time for head casing part schrew making (continuous)

\begin{tabular}{|c|c|c|c|c|}
\hline No. & Initial Activity & $\begin{array}{c}\text { Time } \\
\text { (second) }\end{array}$ & $\begin{array}{l}\text { Internal } \\
\text { set up }\end{array}$ & $\begin{array}{c}\text { Eksternal } \\
\text { set up }\end{array}$ \\
\hline 17 & $\begin{array}{l}\text { Take the casing } \\
\text { head test from the } \\
\text { chuck }\end{array}$ & 5,50 & V & \\
\hline 18 & $\begin{array}{l}\text { Checking the } \\
\text { casing head of the } \\
\text { trial using the } \\
\text { vernier caliper }\end{array}$ & 23,57 & & V \\
\hline 19 & $\begin{array}{l}\text { Installing the test } \\
\text { head casing }\end{array}$ & 16,13 & V & \\
\hline 20 & $\begin{array}{l}\text { Position settings } \\
\text { for tools and dies }\end{array}$ & 114,07 & V & \\
\hline 21 & $\begin{array}{l}\text { Engine testing } \\
\text { process }\end{array}$ & 20,24 & V & \\
\hline 22 & $\begin{array}{l}\text { Take the casing } \\
\text { head test from the } \\
\text { chuck }\end{array}$ & 4,55 & V & \\
\hline 23 & $\begin{array}{l}\text { Check the head } \\
\text { casing with } \\
\text { Vernier Caliper }\end{array}$ & 22,91 & & V \\
\hline 24 & $\begin{array}{l}\text { The process of } \\
\text { making different } \\
\text { types of casing } \\
\text { head screws }\end{array}$ & 20,44 & V & \\
\hline & TOTAL : & 1560,92 & 970,46 & 590,46 \\
\hline
\end{tabular}

\section{Make Improvement}

a. Merging activities

Based on the activity set-up table of machines in table 4.2, operators carry out alternating activities to take new tools and then take dies that are located in storage warehouses that have long distances. These two movements can be combined by bringing tools and dies together so that they can save time.

b. Provision of storage shelves

Storage racks of tools and dies are provided which are placed next to the manual manual lathe to save time the operator walks to the storage warehouse.

c. Operator training

Training is carried out for operators so that the skill increases and can eliminate trial \& error activities. Activity and cycle time after improvements
TABLE 5. Existing activity and cycle time for head casing

\begin{tabular}{clccc}
\hline No. & Initial Activity & $\begin{array}{c}\text { Time } \\
\text { (second) }\end{array}$ & $\begin{array}{c}\text { Internal } \\
\text { set up }\end{array}$ & $\begin{array}{c}\text { Eksternal } \\
\text { set up }\end{array}$ \\
\hline No. & Initial Activity & $\begin{array}{c}\text { Time } \\
\text { second })\end{array}$ & $\mathrm{V}$ & \\
\hline 1 & $\begin{array}{l}\text { Place the LF-2 } \\
\text { worktop type } \\
\text { casing }\end{array}$ & 59,80 & & $\mathrm{~V}$ \\
\hline 2 & $\begin{array}{l}\text { Take tools and } \\
\text { dies on a storage } \\
\text { rack }\end{array}$ & 4,98 & $\mathrm{~V}$ & \\
\hline 3 & $\begin{array}{l}\text { Place tools and } \\
\text { workbench }\end{array}$ & 4,98 & $\mathrm{~V}$ & \\
\hline 4 & $\begin{array}{l}\text { Take tools and } \\
\text { demolition dies }\end{array}$ & 278,24 & $\mathrm{~V}$ & \\
\hline 5 & $\begin{array}{l}\text { Place the tools and } \\
\text { dies that are } \\
\text { dismantled at the } \\
\text { work desk }\end{array}$ & 4,98 & $\mathrm{~V}$ & \\
\hline 6 & $\begin{array}{l}\text { Take tools and } \\
\text { install new dies }\end{array}$ & 357,80 & \\
\hline 7 & $\begin{array}{l}\text { Returns old dies to } \\
\text { the storage rack }\end{array}$ & 40,02 & $\mathrm{~V}$ \\
\hline 8 & $\begin{array}{l}\text { Install the LF-2 } \\
\text { type head casing } \\
\text { on the manual } \\
\text { lathe stand }\end{array}$ & $\begin{array}{l}\text { Position settings } \\
\text { for tools and dies }\end{array}$ & 15,39 & \\
\hline 10 & $\begin{array}{l}\text { The process of } \\
\text { making different } \\
\text { types of casing } \\
\text { head screws }\end{array}$ & 20,44 & \\
\hline & TOTAL: & 905,45 & 790,69 & 114,76 \\
\hline & & & \\
\hline
\end{tabular}

Calculation of production costs per month

a. Existing :

Total production/day :

$$
\begin{aligned}
& \frac{\text { Availability time-( } 5 x \text { set up time })}{\text { Cycle time }} \\
& \frac{7 x 3600-(5 x 1540,48)}{170,11}=102 \mathrm{part} / \mathrm{day}
\end{aligned}
$$

b. After improvement :

Total production/day :

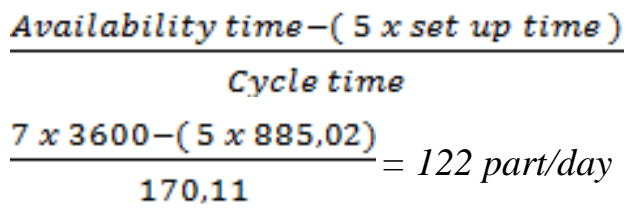




\section{ANALYSIS}

Before and After Improvement with SMED Analysis.

The table below shows a comparison of set-up time and total production.

TABLE 6. The comparison of set up time \& total production before and after improvement

\begin{tabular}{clcc}
\hline No. & Category & Existing & $\begin{array}{c}\text { After } \\
\text { Improvement }\end{array}$ \\
\hline 1. & Set up time & $1540,48 \mathrm{~s}$ & $885,02 \mathrm{~s}$ \\
\hline 2. & $\begin{array}{l}\text { Total } \\
\text { production/day }\end{array}$ & 102 & 122 \\
\hline
\end{tabular}

\section{Current State and Future State Process Activity Mapping Analysis}

The table below shows the comparison of the current state and future state of PAM.

TABLE 7. The comparison between curren state and future state PAM

\begin{tabular}{|c|c|c|c|}
\hline Category & $\begin{array}{c}\text { Current } \\
\text { State PAM } \\
\text { (second) }\end{array}$ & $\begin{array}{c}\text { Future } \\
\text { State PAM } \\
\text { (second) }\end{array}$ & Reason \\
\hline Lead Time & 22105,54 & 21450,07 & \multirow{4}{*}{$\begin{array}{l}\text { After } \\
\text { improvement } \\
\text { with SMED, } \\
\text { the activity } \\
\text { of manual } \\
\text { lathe set-up } \\
\text { in the } \\
\text { process of } \\
\text { making part } \\
\text { head casing } \\
\text { is faster }\end{array}$} \\
\hline $\begin{array}{l}\text { Value } \\
\text { Added }\end{array}$ & 12615,51 & 7186,14 & \\
\hline $\begin{array}{c}\text { Neccesary } \\
\text { Non Value } \\
\text { Added }\end{array}$ & 5089,21 & 4972,52 & \\
\hline $\begin{array}{c}\text { Non Value } \\
\text { Added }\end{array}$ & 4400,82 & 245,37 & \\
\hline
\end{tabular}

\section{CONCLUSION}

Based on the explanation above, the company is advised to run the proposal given by the author, because it can increase productivity, especially in the production of head casing part. The proposal above does not require a relatively large cost, only requires operator adaptation in carrying out the design of the proposed activity.

\section{REFERENCES}

Franchetti, M. J. (2015). Lean Six Sigma for Engineers and Managers: With Applied Case Studies. CRC Press,
Year: 2015.

Ledbetter, P. (2018). The Toyota Template:

The Plan for Just-In-Time and Culture

Change Beyond Lean Tools.

Productivity Press;Taylor and Francis, Year: 2018.

Iftikar Z. Sutalaksana, Ruhana Anggawisastra, J. H. T. (2006). Teknik perancangan sistem kerja. Bandung: ITB Bandung, Year: 2006

Antony, J. (2016). Lean Six Sigma for Small and Medium Sized Enterprises. For Dummies. CRC Press, Year: 2016.

Herr, K. (2013). Quick Changeover Concepts Applied: Dramatically Reduce Set-Up Time and Increase Production Flexibility with SMED. CRC Press, Year: 2013. 